\title{
Effect of Insulin Replacement on Intermediary Metabolism in Diabetes Secondary to Pancreatectomy
}

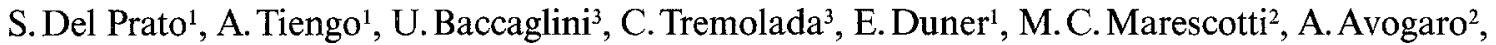 \\ I. Valverde ${ }^{4}$, R. Nosadini' ${ }^{1}$ and R. Assan ${ }^{5}$ \\ 'Cattedra di Malattie del Ricambio, ${ }^{2}$ Cattedra di Patologia Medica, and ${ }^{3}$ Clinica Chirurgica III, University of Padua, Italy, \\ ${ }^{4}$ Fundacion Jiménez Diaz, Independent University of Madrid, Spain, and ${ }^{5}$ Diabetes Department, Hôpital Bichat, Paris, France
}

\begin{abstract}
Summary. Patients with diabetes due to pancreatectomy have metabolic features different from Type 1 (insulin-dependent) diabetes after insulin withdrawal. Whether or not glucagon by itself or combined glucagon-insulin absence are responsible for this metabolic behaviour is unknown. This study was carried out to evaluate the ability of insulin replacement to abolish differences between patients with Type 1 diabetes and patients with diabetes due to pancreatectomy. We studied the diurnal patterns of intermediary metabolites, free insulin, and glucagon using the Biostator (glucose-controlled insulin infusion system) and intensive subcutaneous insulin therapy in five patients after total pancreatectomy, five after partial pancreatectomy and seven patients with Type 1 diabetes. All were studied for $24 \mathrm{~h}$ after an overnight period of normoglycaemia. Insulin requirement was lower in the patients with total pancreatectomy than in patients with partial pancreatectomy or Type 1 diabetes during both types of insulin treatment $(p<$ 0.05 ). Blood glucose and free insulin were similar in all the groups in both conditions. Immunoreactive glucagon was higher in the patients with diabetes secondary to pancreatectomy than in Type 1 diabetic patients. However, glucagon levels did not increase after arginine infusion in the patients with total pancreatectomy, and column chromatography of blood samples from two totally pancreatectomized patients showed
\end{abstract}

no significant levels of immunoreactive pancreatic glucagon. Non-esterified fatty acids and ketone bodies were similar during Biostator and intensive subcutaneous insulin therapy. By contrast, gluconeogenic precursors (lactate, pyruvate, alanine and glycerol) were higher in patients with total pancreatectomy than in patients with partial pancreatectomy and Type 1 diabetes. In particular, alanine was significantly higher in the patients with total pancreatectomy $(400 \pm 50 \mu \mathrm{mol} / 1$ during Biostator; $437 \pm 62 \mu \mathrm{mol} / 1$ during intensive subcutaneous insulin therapy) than in patients with partial pancreatectomy $(207 \pm 13 \mu \mathrm{mol} / \mathrm{l}, p<0.005$ and $226 \pm 14 \mu \mathrm{mol} / \mathrm{I}, p<0.005)$ and in Type 1 diabetic patients $(191 \pm 11 \mu \mathrm{mol} / 1, p<0.005$ and $216 \pm 10 \mu \mathrm{mol} / 1, p<0.005)$. Our data show that the high levels of gluconeogenic precursors, already reported in patients with diabetes due to total pancreatectomy after insulin withdrawal, do not become normal even in the presence of insulin. This finding shows that gluconeogenesis is primarily dependent on pancreatic glucagon and confirms the role of glucagon in the development of diabetic hyperglycaemia.

Key words: Pancreatogenic diabetes, total pancreatectomy, partial pancreatectomy, glucagon, free insulin, gluconeogenesis, intermediary metabolism.
Glucagon has been reported to be essential for the development of biochemical abnormalities of diabetes mellitus [1-4], where the absence of insulin is accompanied by relative or absolute hyperglucagonaemia [5-8]. The observations that pharmacological doses of glucagon increase ketogenesis, lipolysis [3-9], and hyperglycaemia are in agreement with this hypothesis. In Type 1 (insulin-dependent) diabetes glucagon suppression by somatostatin can delay the development of ketoacidosis after insulin withdrawal [10]. Clinical and metabolic features characterizing diabetes secondary to pancreatectomy have often been related to glucagon deficiency. In particular, the easier control of hypergly- caemia with a low daily insulin requirement [11], the high frequency of severe hypoglycaemic events [12], and the lower tendency to ketoacidotic coma were all ascribed to the absence of glucagon [13]. Following prolonged insulin withdrawal, patients with diabetes due to total pancreatectomy exhibit elevated levels of gluconeogenetic precursors [14] and decreased ketone body concentrations [15-16] in comparison with Type 1 diabetic patients.

Whether or not insulin restoration can reverse this metabolic pattern and abolish the differences between Type 1 and pancreatectomized diabetic patients is unknown. Furthermore, evaluation of metabolic behav- 
Table 1. Clinical data of the subjects studied

\begin{tabular}{|c|c|c|c|c|c|c|c|c|c|}
\hline Diabetic patients & $\begin{array}{l}\text { Age } \\
\text { (years) }\end{array}$ & $\begin{array}{l}\text { Ideal body } \\
\text { weight } \\
(\%)\end{array}$ & $\begin{array}{l}\mathrm{HbA}_{1} \\
(\%)\end{array}$ & \multicolumn{2}{|l|}{ C-peptide } & $\begin{array}{l}\text { Aspartate } \\
\text { transferase }{ }^{\mathrm{a}} \\
(\mathrm{U} / \mathrm{l})\end{array}$ & $\begin{array}{l}\text { Alanine } \\
\text { transferase }^{\mathrm{a}} \\
(\mathrm{U} / \mathrm{l})\end{array}$ & $\begin{array}{l}\text { Bilirubin }^{a} \\
(\mu \mathrm{mol} / \mathrm{l})\end{array}$ & $\begin{array}{l}\text { Serum } \\
\text { protein }^{a} \\
(\mathrm{~g} / 1)\end{array}$ \\
\hline $\begin{array}{l}\text { Totally pancreat- } \\
\text { ectomized }(n=5)\end{array}$ & $53 \pm 4$ & $96 \pm 4$ & $8.6 \pm 0.7$ & $0.09 \pm 0.01$ & $0.09 \pm 0.03$ & $30 \pm 7$ & $40 \pm 8$ & $20.6 \pm 3.4$ & $65 \pm 2$ \\
\hline $\begin{array}{l}\text { Partially pancreat- } \\
\text { ectomized }(n=5)\end{array}$ & $47 \pm 3$ & $103 \pm 3$ & $9.6 \pm 4$ & $0.14 \pm 0.04$ & $0.15 \pm 0.01$ & $44 \pm 5$ & $51 \pm 12$ & $15.6 \pm 6.9$ & $67 \pm 3$ \\
\hline
\end{tabular}

Results expressed as mean \pm SEM.

a Normal ranges: aspartate transaminase $<40 \mathrm{U} / 1$; alanine transaminase $<50 \mathrm{U} / 1$; bilirubin $3-17$ umol $/ 1$; serum protein $60-80 \mathrm{~g} / 1$

iour after insulin restoration in patients with glucagon deficiency may furnish further information on the glucagon-insulin relationship in the development of metabolic disorders in diabetes. We have therefore studied the diurnal behaviour of the main circulating substrates of gluconeogenesis, lipolysis, and ketogenesis in patients with diabetes secondary to partial or total pancreatectomy and in Type 1 diabetic patients kept under strict glycaemic control by means of an artificial endocrine pancreas or intensive subcutaneous insulin therapy.

\section{Subjects and Methods}

\section{Subjects}

Five patients with insulin-dependent diabetes secondary to total pancreatectomy, five subjects with diabetes secondary to partial pancreatectomy, and seven subjects with Type 1 diabetes were studied. The main clinical characteristics of the subjects are shown in Table 1. Four of the five pancreatectomized patients had undergone surgery for exocrine pancreatic carcinoma and the fifth for recurrent chronic pancreatitis with uncontrollable abdominal pain. The pancreas had been removed together with the duodenum, spleen and antropyloric twothirds of the stomach in all cases. During surgery no liver metastases had been found in the patients with carcinoma. Surgery had been performed at least 6 months before this study, when the body weight was $\geqslant 90 \%$ of ideal body weight and the liver function was normal (Table 1). In the second group, partial pancreatectomy had followed the diagnosis of chronic pancreatitis, which was based on the presence of chronic diarrhoea and steatorrhoea, abdominal pain and radiological evidence of pancreatic calcification. Most of these patients were chronic alcohol abusers, but the quantitative estimate of the daily alcohol intake was $<40 \mathrm{~g} /$ day in the month preceding this study. The patients with diabetes secondary to pancreatitis had abnormal liver function, as judged by high transaminase levels (Table 1). Patients with secondary diabetes had no family history of diabetes. The Type 1 diabetic subjects had no exocrine pancreatic pathology. All the patients were admitted to hospital one week before the study and underwent insulin treatment with three daily injections of regular insulin and one of long-acting insulin in the evening (Actrapid and Monotard, Novo, Denmark). An isocaloric diet was administered to all the patients. The subjects with diabetes secondary to total pancreatectomy were placed on a carbohydrate-rich diet $(300 \mathrm{~g} /$ day $)$ with low fat content $(20 \mathrm{~g} /$ day). These patients were also given a pancreatic enzyme supplement (Pancrex V forte, Paines \& Byrne, Samil, Rome, Italy; 330 units of protease activity and 5600 units of lipase activity per tablet).

\section{Protocol}

After an overnight period of normoglycaemia achieved by means of continuous intravenous insulin infusion (Actrapid) at a rate of 0.6-1.0 U/h (Harvard Apparatus, Millis, Massachusetts, USA) all the subjects had two intensive glucose control periods. Insulin infusion was stopped before each control period. The diet was administered as three meals (breakfast $08.00 \mathrm{~h}$, lunch $12.00 \mathrm{~h}$, dinner $18.00 \mathrm{~h}$ ) and three snacks at $10.30,16.00$ and $22.00 \mathrm{~h}$. The patients were kept at rest during the study period. A Teflon catheter was placed in an antecubital vein for collection of blood samples.

The first glucose control period was performed by means of an artificial endocrine pancreas (Biostator glucose-controlled insulin infusion system; Life Science Instruments, Ulm, FRG). The patients were connected to the Biostator via a double lumen catheter $30 \mathrm{~min}$ before breakfast. Another catheter was inserted in a superficial vein for insulin infusion according to the control algorithm. The operating constants were: the constant for rising glucose levels $(K R)=165$ and for falling glucose levels $(K F)=45$; the inverse of the static gain for insulin infusion (QI) $=30$; the basal level of glucose at which the basal insulin infusion rate $(\mathrm{RI}=15 \mathrm{mU} / \mathrm{min})$ was administered was $4.5 \mathrm{mmol} / \mathrm{l}(\mathrm{BI})$. Blood samples $(n=9)$ were collected immediately before, and $1 \mathrm{~h}$ after each meal and at 16.00,22.00, and $08.00 \mathrm{~h}$.

The second glucose control period was performed by means of intensive SC insulin treatment. Regular insulin (Actrapid, Novo, Denmark) was administered 15 min before each meal. Long-acting insulin (Monotard, Novo, Denmark) was also injected before dinner. Insulin doses during the control period were estimated according to the insulin requirement in the days preceding the study and suitably changed on the basis of rapid blood glucose measurements (Dextrometer, Ames Division, Miles Research Laboratories, Elkhart, Indiana, USA). Blood samples $(n=14)$ were collected at $08.00,08.30,09.00$, $10.00,12.00,12.30,13.00,14.00,16.00,18.00,18.30,19.00,24.00$, $08.00 \mathrm{~h}$.

\section{Arginine Infusion Test}

An arginine infusion test was performed in all the patients after an overnight fast. Arginine $\mathrm{HCl}(25 \mathrm{~g})$ dissolved in sterile pyrogen-free water was infused into an antecubital vein at a constant flow rate for $30 \mathrm{~min}$. Blood samples were drawn from a controlateral antecubital vein at $0,5,15,30,45,60 \mathrm{~min}$ for glucagon determination.

\section{Assays}

Blood $(2 \mathrm{ml})$ was collected in $5 \%$ perchloric acid for the determination of glucose, lactate, pyruvate, alanine, glycerol, and 3-hydroxybutyrate according to Lloyd et al. [17], and acetoacetate according to Price et al. [18]. Blood was also collected in tubes containing $1.2 \mathrm{mg}$ EDTA and 
aprotinin $500 \mathrm{U} / \mathrm{ml}$ (Trasylol, Bayer, FRG) for the determination of non-esterified fatty acids (NEFA [19]), free insulin [20], and immunoreactive glucagon using the $30 \mathrm{~K}$ antibody [21]. Basal samples were taken for measurement of glycosylated haemoglobin [22] and C-peptide. This hormone was also evaluated $1 \mathrm{~h}$ after meals. C-peptide was measured by means of the RIA-mat kit (Byk-Mallinckrodt Pharmazeutikal, Dietzenbach, FRG) [23]. The lowest sensitivity in our laboratory is $0.07 \mathrm{pmol} / 1$. Transaminase, bilirubin and serum protein were assayed by means of a high speed computer controlled biochemical analyzer (Technicon Instruments Corporation, New York, USA).

\section{Gel Chromatography}

Plasma immunoreactive glucagon components were assayed in two patients with total pancreatectomy by gel chromatography according to Valverde et al. [24-25]. An aliquot of basal plasma sample ( $2 \mathrm{ml})$ was filtered over Bio-Gel P30 columns $(40 \times 1 \mathrm{~cm})$ and eluted with $0.05 \mathrm{~mol} / \mathrm{l}$ ammonium bicarbonate buffer $(\mathrm{pH} 8.8)$ at a flow rate of $10 \mathrm{ml} / \mathrm{h}$. Columns were calibrated with ${ }^{125} \mathrm{I}$-glucagon, ${ }^{125} \mathrm{I}$-insulin and ${ }^{125} \mathrm{I}$. Eluates $(1 \mathrm{ml})$ were collected, counted for radioactivity, and immunoreactive glucagon measured with $30 \mathrm{~K}$ antibody [21].

\section{Calculations}

Values are expressed as mean \pm SEM. Mean $24 \mathrm{~h}$ values are calculated as the average of nine blood samples during Biostator control and 14 samples during intensive insulin therapy. The $M$ value of Schlichtkrull is calculated on the same samples according to Service et al. [26]. Statistical elaboration has been performed according to the analysis of variance. Every time the analysis of variance showed a significant difference among the groups, a multiple comparison according to Newman-Keuls test [27-28] in order to estimate the differences between each group was performed.

\section{Results}

\section{Blood Glucose (Fig. 1 and Table 2)}

Blood glucose after the overnight insulin infusion was similar in all the groups (totally pancreatectomized diabetic patients: $5.1 \pm 0.7$; partially pancreatectomized diabetic patients: $4.8 \pm 0.5$ and Type 1 diabetic patients: $5.7 \pm 0.7 \mathrm{mmol} / 1)$ and before intensive SC insulin therapy $(5.2 \pm 0.8 ; 4.4 \pm 0.6$ and $4.7 \pm 0.8 \mathrm{mmol} / 1$ respective1y). The daily glycaemic profile, $24 \mathrm{~h}$ glycaemic mean and Schlichtkrull's $M$ value with both treatments were
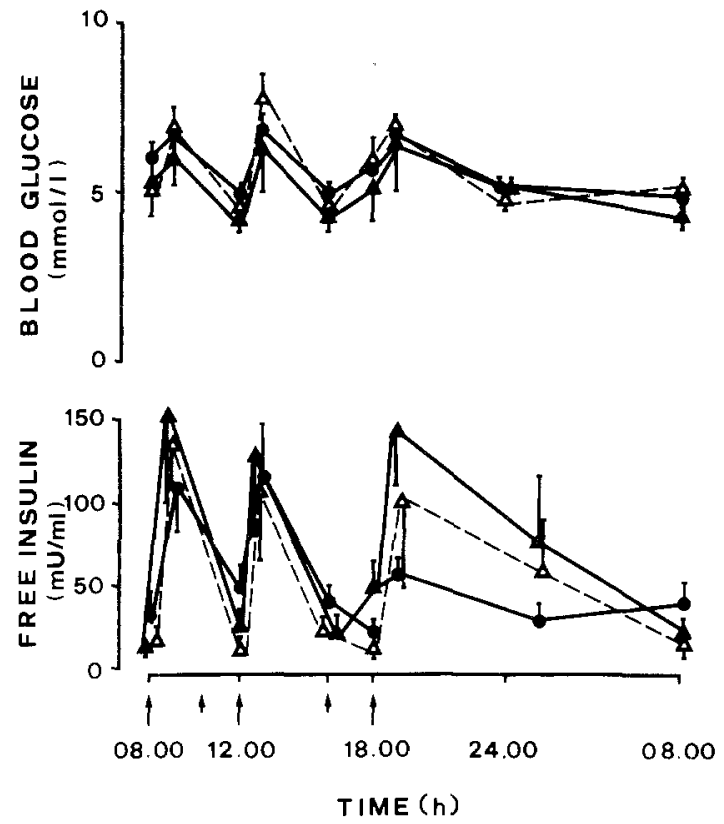

Fig. 1. Blood glucose and free insulin levels (mean \pm SEM) during 24-h Biostator control in patients with diabetes due to total pancreatectomy $(\Delta-\triangle \Delta)$, partial pancreatectomy $(\mathbf{\Delta}-\mathbf{\Lambda})$ and patients with Type 1 diabetes $(\longrightarrow)$. Arrows indicate meal and snack times

similar in the three groups (Table 2). Glycaemic control was better with the Biostator than with $\mathrm{SC}$ insulin therapy.

\section{Free Insulin (Fig. 1 and Table 2)}

Insulin requirement was significantly lower $(p<0.05)$ in totally pancreatectomized patients in comparison with the other two groups. The diurnal profile of free insulin levels and the 24 -h mean value were quite similar in all groups, though diabetic subjects with partial pancreatectomy showed a tendency to higher levels of free insulin.

Table 2. Index of 24-h glucose control and hormone levels under Biostator and intensive SC insulin therapy in Type 1 diabetic patients and patients with diabetes secondary to total and partial pancreatectomy

\begin{tabular}{|c|c|c|c|c|c|c|}
\hline Group & Treatment & $\begin{array}{l}\text { Blood glucose } \\
(\mathrm{mmol} / \mathrm{l})\end{array}$ & $\begin{array}{l}\text { ' } M \text { ' value } \\
{[26]}\end{array}$ & $\begin{array}{l}\text { Insulin } \\
\text { requirement } \\
\text { (U/24h) }\end{array}$ & $\begin{array}{l}\text { Free insulin } \\
(\mathrm{mU} / 1)\end{array}$ & $\begin{array}{l}\text { Immunoreac- } \\
\text { tive glucagon } \\
(\mathrm{pg} / \mathrm{ml})\end{array}$ \\
\hline $\begin{array}{l}\text { Type } 1 \text { diabetes } \\
\quad(n=7)\end{array}$ & $\begin{array}{l}\text { Biostator } \\
\text { Intensive SC insulin }\end{array}$ & $\begin{array}{l}3.18 \pm 0.06 \\
3.73 \pm 0.37\end{array}$ & $\begin{array}{r}1.8 \pm 0.7 \\
10 \quad \pm 2.5\end{array}$ & $\begin{array}{l}62 \pm 5 \\
66 \pm 6\end{array}$ & $\begin{array}{l}63 \pm 16 \\
50 \pm 7\end{array}$ & $\begin{array}{l}138 \pm 15 \\
123 \pm 84\end{array}$ \\
\hline $\begin{array}{l}\text { Totally pancreatectomy } \\
\qquad(n=5)\end{array}$ & $\begin{array}{l}\text { Biostator } \\
\text { Intensive SC insulin }\end{array}$ & $\begin{array}{l}3.09 \pm 0.07 \\
3.61 \pm 0.62\end{array}$ & $\begin{array}{l}1.2 \pm 0.6 \\
5.9 \pm 5.4\end{array}$ & $\begin{array}{l}44 \pm 12^{\mathrm{a}, \mathrm{b}} \\
47 \pm 7^{\mathrm{a}, \mathrm{b}}\end{array}$ & $\begin{array}{l}53 \pm 10 \\
54 \pm 8\end{array}$ & $\begin{array}{l}202 \pm 50 \\
223 \pm 35\end{array}$ \\
\hline $\begin{array}{l}\text { Partially pancreatectomy } \\
\quad(n=5)\end{array}$ & $\begin{array}{l}\text { Biostator } \\
\text { Intensive SC insulin }\end{array}$ & $\begin{array}{l}3.21 \pm 0.09 \\
3.77 \pm 0.34\end{array}$ & $\begin{array}{l}4.8 \pm 1.0 \\
7.0 \pm 2.0\end{array}$ & $\begin{array}{l}70 \pm 8 \\
60 \pm 1\end{array}$ & $\begin{array}{l}68 \pm 10 \\
75 \pm 13\end{array}$ & $\begin{array}{l}248 \pm 101 \\
300 \pm 99\end{array}$ \\
\hline
\end{tabular}

Results expressed as mean \pm SEM. ${ }^{a} p<0.05$ Total pancreatectomized versus Type 1 diabetic patients $;{ }^{b} p<0.05$ Total pancreatectomized versus partial pancreatectomized diabetic patients 


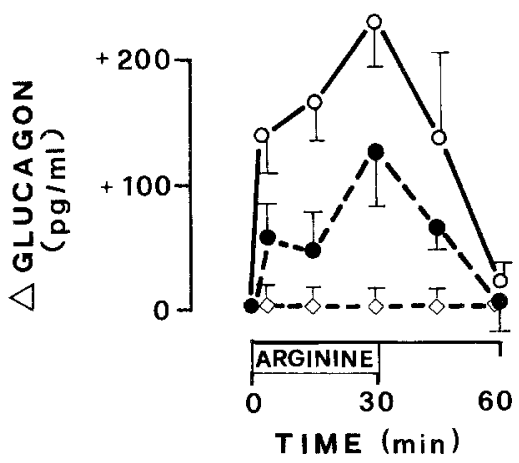

Fig. 2. Absolute increments of total glucagon immunoreactivity (mean $\pm \mathrm{SEM}$ ) above basal concentrations, during arginine infusion test in patients with diabetes due to total pancreatectomy $(\diamond-\diamond)$ partial pancreatectomy (-..- and Type 1 diabetic patients $(\mathrm{O}-\mathrm{O})$

\section{Glucagon}

Figure 2 shows the absolute increment in glucagon values after arginine infusion. Glucagon rapidly increased in patients with Type 1 diabetes, whereas no variations were observed in totally pancreatectomized subjects. Patients with diabetes secondary to partial pancreatectomy had an intermediate glucagon response. Increased levels of immunoreactive glucagon were found in patients with diabetes due to total and partial pancreatectomy under Biostator as well as intensive SC insulin treatment (Table 2). Gel-chromatography revealed no immunoreactive glucagon eluting with ${ }^{125}$ I-glucagon (mol wt: 3,500).

\section{Lactate}

Lactate levels at the beginning of the Biostator period were comparable in the three groups. After meals, there was an increase in lactate levels, which were higher in patients with total pancreatectomy (after breakfast: $1453 \pm 207 \mu \mathrm{mol} / 1$ in totally pancreatectomized diabetic patients; $970 \pm 142 \mu \mathrm{mol} / 1$ in partially pancreatectomized diabetic patients, $p<0.05 ; 905 \pm 63 \mu \mathrm{mol} / 1$ in Type 1 diabetic patients, $p<0.05$; Fig. 3). Mean $24 \mathrm{~h} \mathrm{lev-}$ els of lactate (Table 3 ) were higher in the totally pancreatectomized $(946 \pm 90 \mu \mathrm{mol} / 1)$ compared with partially pancreatectomized $(808 \pm 42 \mu \mathrm{mol} / \mathrm{l})$ and Type 1 diabetic patients $(762 \pm 46 \mu \mathrm{mol} / \mathrm{l}$; Table 3$)$. The same results were found with intensive SC insulin treatment. Blood lactate levels in pancreatectomized diabetic patients were higher at the beginning of the control period (totally pancreatectomized diabetic patients: $917 \pm$ $83 \mu \mathrm{mol} / 1$; partially pancreatectomized diabetic patients: $517 \pm 77 \mu \mathrm{mol} / 1, p<0.005$; Type 1 diabetic patients: $694 \pm 73 \mu \mathrm{mol} / 1, p<0.05)$ and after meals.

\section{Pyruvate}

The profile of pyruvate levels was parallel to lactate behaviour. Plasma concentrations of pyruvate during $24 \mathrm{~h}$

\section{BIOSTATOR CONTROL}

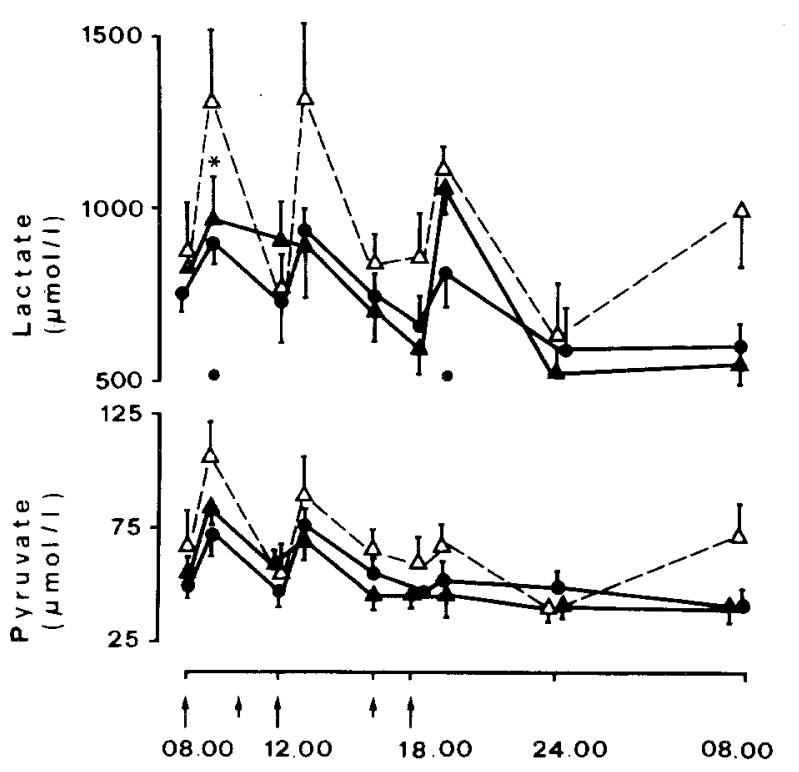

\section{INTENSIVE S C INSULIN THERAPY}

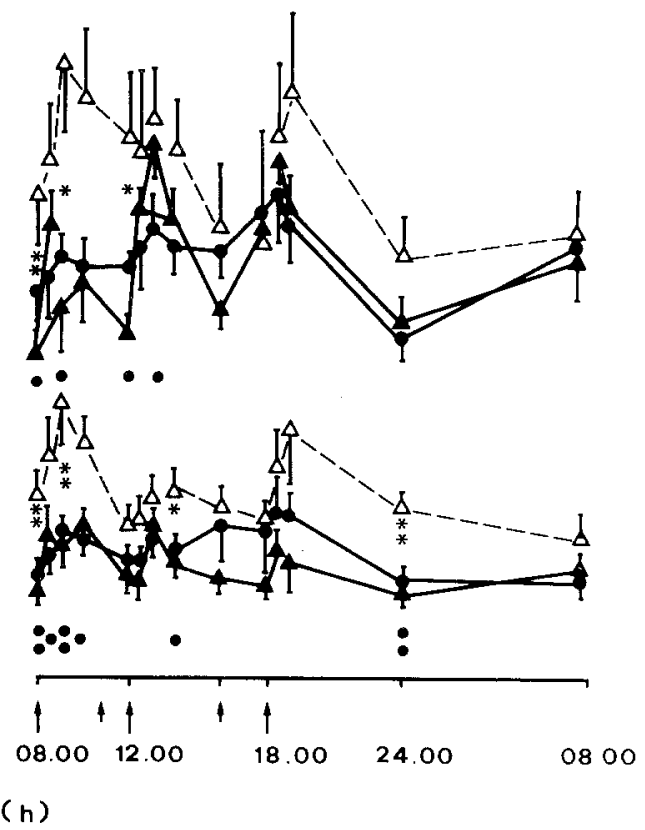

Fig.3. Diurnal profile of plasma lactate and pyruvate concentrations (mean \pm SEM) in patients with diabetes due to total pancreatectomy $(\triangle--\Delta)$ compared with patients with diabetes due to partial pancreatectomy $\left(\Delta-\mathbf{\wedge},{ }^{*} p<0.05 ; * * 0.005\right)$ and Type 1 diabetic patients - $p<0.05 ;:<<0.005)$. Arrows indicate meal and snack times. Left hand panel: Biostator control, right hand panel: intensive SC insulin therapy 
Table 3. Twenty-four hour intermediary metabolite levels in patients with diabetes due to total or partial pancreatectomy or Type 1 diabetes during Biostator control and intensive subcutaneous insulin therapy

\begin{tabular}{|c|c|c|c|c|c|c|}
\hline \multirow{2}{*}{$\begin{array}{l}\text { Intermediary } \\
\text { metabolite } \\
(\mu \mathrm{mol} / 1)\end{array}$} & \multicolumn{3}{|l|}{ Biostator } & \multicolumn{3}{|c|}{ Intensive conventional insulin therapy } \\
\hline & $\begin{array}{l}\text { Totally } \\
\text { pancreatectomized } \\
\text { patients }\end{array}$ & $\begin{array}{l}\text { Partially } \\
\text { pancreatectomized } \\
\text { patients }\end{array}$ & $\begin{array}{l}\text { Type } 1 \\
\text { diabetic } \\
\text { patients }\end{array}$ & $\begin{array}{l}\text { Totally } \\
\text { pancreatectomized } \\
\text { patients }\end{array}$ & $\begin{array}{l}\text { Partially } \\
\text { pancreatectomized } \\
\text { patients }\end{array}$ & $\begin{array}{l}\text { Type } 1 \\
\text { diabetic } \\
\text { patients }\end{array}$ \\
\hline Lactate & $946 \pm 90$ & $808 \pm 42$ & $762 \pm 46$ & $1073 \pm 105^{\mathrm{a}, \mathrm{b}}$ & $792 \pm 76$ & $707 \pm 49$ \\
\hline Pyruvate & $67 \pm 8$ & $57 \pm 3$ & $57 \pm 3$ & $82 \pm 8^{\mathrm{a}, \mathrm{c}}$ & $47 \pm 5$ & $56 \pm 5$ \\
\hline Alanine & $400 \pm 50^{\mathrm{b}, \mathrm{d}}$ & $207 \pm 13$ & $191 \pm 11$ & $437 \pm 62^{b, d}$ & $226 \pm 14$ & $216 \pm 10$ \\
\hline Glycerol & $53 \pm 14$ & $32 \pm 7$ & $33 \pm 2$ & $60 \pm 8^{a, c}$ & $33 \pm 6$ & $35 \pm 4$ \\
\hline NEFA & $401 \pm 43$ & $306 \pm 23$ & $492 \pm 112$ & $374 \pm 35$ & $276 \pm 15$ & $335 \pm 37$ \\
\hline Ketone bodies & $133 \pm 17$ & $158 \pm 27$ & $149 \pm 25$ & $150 \pm 17$ & $109 \pm 13$ & $180 \pm 43$ \\
\hline
\end{tabular}

Results expressed as mean \pm SEM. ${ }^{\mathrm{a}} p<0.05,{ }^{\mathrm{b}} p<0.005$, total pancreatectomized versus partial pancreatectomized diabetic patients; ${ }^{\mathrm{c}} p<0.05$, $\mathrm{d} p<0.005$, total pancreatectomized versus Type 1 diabetic patients

BIOSTATOR CONTROL

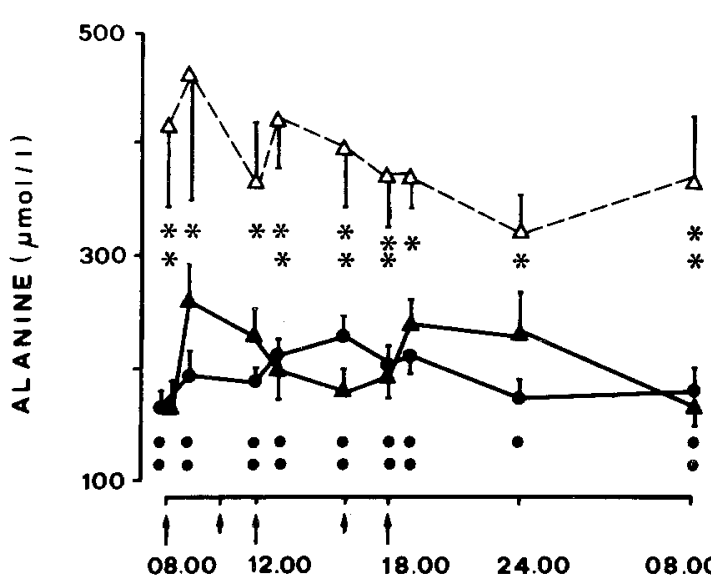

INTENSIVE SC INSULIN THERAPY
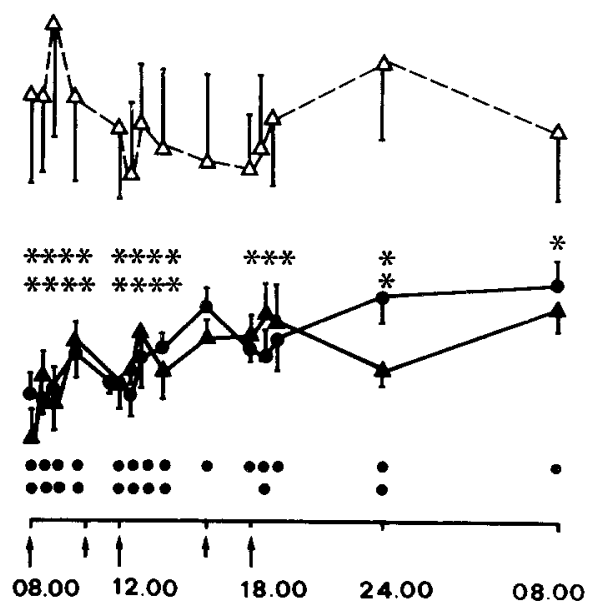

TIME (h)

Fig.4. Diurnal profile of plasma alanine concentrations (mean \pm SEM) in patients with diabetes due to total pancreatectomy $(\Delta--\Delta)$ compared with patients with diabetes due to partial pancreatectomy $(\Lambda-\mathbf{\Lambda}, * p<0.05 ; * p<0.005)$ and Type 1 diabetic patients $(\bullet-$ - $p<0.05 ; p<0.005)$. Arrows indicate meal and snack times. Left hand panel: Biostator control, right hand panel: intensive SC insulin therapy

of glycaemic control by Biostator were consistently slightly higher in totally pancreatectomized diabetic patients than in the other two groups (Fig. 3). Mean $24 \mathrm{~h}$ levels of pyruvate were significantly increased in totally pancreatectomized diabetic patients (Table 3 ). During intensive SC insulin therapy the diurnal pyruvate profile (Fig. 3) and the 24-h mean levels (Table 3) were higher in totally pancreatectomized diabetic patients than in partially pancreatectomized and Type 1 diabetic subjects.

\section{Alanine}

At the beginning of the two control periods alanine was significantly higher in totally pancreatectomized diabetic patients (Biostator: totally pancreatectomized patients: $416 \pm 81 \mu \mathrm{mol} / \mathrm{l}$; partially pancreatectomized patients: $175 \pm 23 \mu \mathrm{mol} / 1, p<0.005$; Type 1 diabetic patients: $174 \pm 13 \mu \mathrm{mol} / 1, p<0.005$; intensive $\mathrm{SC}$ insulin therapy: $403 \pm 37 ; 194 \pm 24, p<0.005 ; 189 \pm 18 \mu \mathrm{mol} / 1$, $p<0.005$, respectively). Alanine levels were almost double throughout the whole day in the totally pancreatectomized patients compared with the other groups, both during Biostator use and during intensive SC insulin therapy (Fig.4). No apparent variations in alanine levels were observed at meal times. During both Biostator or intensive SC insulin therapy, the mean $24 \mathrm{~h} \mathrm{lev-}$ els of alanine were significantly higher in the patients with diabetes secondary to total pancreatectomy than in the subjects with partial pancreatectomy $(p<0.005)$ or Type 1 diabetes $(p<0.005)$.

\section{Glycerol}

Comparable levels of glycerol were found at the beginning of the two control periods (Biostator: 60 \pm 14 ; $49 \pm 5 ; 45 \pm 9 \mu \mathrm{mol} / \mathrm{l}$; intensive insulin therapy: $78 \pm$ $10 ; 49 \pm 8 ; 54 \pm 16 \mu \mathrm{mol} / 1$ in totally pancreatectomized, 
partially pancreatectomized and Type 1 diabetic patients, respectively). Glycerol levels during Biostator use presented a smooth increase before meals in totally pancreatectomized diabetic patients only. Mean 24-h levels were higher in these patients in comparison with partially pancreatectomized and Type 1 diabetic patients (Table 3 ). In totally pancreatectomized diabetic patients receiving intensive $\mathrm{SC}$ insulin therapy, glycerol levels were slightly increased during the whole study period. A significantly higher $24-\mathrm{h}$ mean concentration was found $(p<0.05)$.

\section{Non-Esterified Fatty Acids (NEFA)}

Diurnal profiles and mean 24-h level of NEFA were not different in the three groups during either Biostator and intensive SC insulin therapy (Table 3). A pre-prandial peak was observed before dinner in all the groups.

\section{Ketone Bodies}

Ketone body levels were not significantly different in the three groups in the morning after an overnight insulin infusion $(126 \pm 18 ; 161 \pm 24$ and $228 \pm 81 \mu \mathrm{mol} / 1$ in patients with total and partial pancreatectomy and Type 1 diabetes respectively before Biostator use and $127 \pm 20 ; 156 \pm 30$ and $274 \pm 87 \mu \mathrm{mol} / 1$ before intensive insulin therapy, Table 3). After Biostator connection, ketone bodies rapidly decreased and remained constant for the rest of the study. Mean 24-h levels overlapped in the three groups.

Ketone body inhibition was similar in all the groups after the injection of regular insulin. Ketone body levels were the same until $24.00 \mathrm{~h}$ in all diabetic patients. In comparison with the Biostator period, when ketone body levels were constantly reduced, a pre-dinner peak was observed. This peak was coincident with a similar peak in glycerol and NEFA levels. A greater increase in ketone body levels was observed in Type 1 diabetic patients, after the last insulin injection, at $08.00 \mathrm{~h}$ (totally pancreatectomized patients: $260 \pm 60 \mu \mathrm{mol} / 1$; partially pancreatectomized patients: $274 \pm 65 \mu \mathrm{mol} / 1$; Type 1 diabetic patients: $503 \pm 145 \mu \mathrm{mol} / \mathrm{l})$.

Mean 24-h ketone body levels were higher in patients with Type 1 diabetes than in patients whose diabetes was secondary to pancreatectomy (Table 3 ).

\section{Discussion}

Our study shows that in diabetes due to totally pancreatectomy the increase in gluconeogenic precursors is a persistent and characteristic metabolic feature. This finding suggests a block of gluconeogenesis from glucidic, aminic, and probably lipidic precursors as a consequence of pancreatic glucagon absence, even in the presence of normal insulin availability. It is noteworthy that the same results were obtained with both Biostator control and intensive subcutaneous insulin therapy. This suggests that such behaviour may be expected during the conventional insulin treatment of pancreatogenic diabetic subjects.

Diabetes secondary to total pancreatectomy has been proposed as a model of 'aglucagonaemic diabetes' [29], even though glucagon immunoreactivity is found in these patients [30-34]. Immunoreactive glucagon was higher in our patients, probably reflecting the non-specificity of $30 \mathrm{~K}$ antibody [24-25] reacting with intestinal glucagon-like substances, which are increased after pancreatectomy [35]. However, the absence of glucagon response to arginine, and the absence (or very small amount) of 3500 molecular weight glucagon suggest deficiency of A cell function. Thus, diabetes due to total pancreatectomy may be considered to be an example of diabetes with a chronic glucagon defect. On the contrary, partially pancreatectomized diabetic patients had a residual glucagon secretion. In fact, they had high immunoreactive glucagon levels during the study period with intermediate glucagon responses to arginine. These patients had impaired liver function which could have been responsible for reduced glucagon clearance [36] and insulin resistance [37]: this could also explain their high insulin requirement. In totally pancreatectomized subjects, glucose control was obtained with lower insulin doses than in Type 1 diabetic patients. The high insulin sensitivity of the former was clinically evident in the high frequency of hyperglycaemic events [12]. We have recently demonstrated increased insulin sensitivity of extrahepatic tissues in pancreatogenic diabetes [38], as opposed to a reduced insulin sensitivity in Type 1 diabetes $[39,40]$.

The free insulin levels were similar in all the groups during Biostator use and intensive subcutaneous insulin therapy, so that the behaviour of intermediary metabolites seems to depend only on the presence of pancreatic glucagon (Type 1 diabetes and partial pancreatectomy) or its absence (total pancreatectomy).

The glucagon defect in totally pancreatectomized diabetic patients seems to account for the decrease in the rate of gluconeogenesis and the consequent increase in gluconeogenic precursors: lactate, pyruvate, and, in particular, alanine. Even though there is no evidence that lactate and pyruvate uptakes are under direct glucagon control, these two final glycolytic metabolites are well-known contributors to hepatic gluconeogenesis [41]. In totally pancreatectomized diabetic patients the increased blood lactate levels are not due to a change in the lactate-dehydrogenase balance, as demonstrated by similar lactate/pyruvate ratios in all the groups (data not shown).

We can conclude that a defect in splanchnic uptake of lactate and pyruvate exists in totally pancreatectomized diabetic patients. However we cannot exclude an enhancement of their production rate. It has been reported that glucagon does not modify lactate production by peripheral tissues [43]. However, the incre- 
ment in peripheral sensitivity to exogenous insulin in these patients [38] could induce enhanced glycolysis. Intrahepatic glycolysis, not counteracted by glucagondependent phosphofructokinase regulation, might represent another source of pyruvate and lactate [44]. This mechanism may explain their high post-prandial response, already observed in pancreatectomized dogs [45].

The most impressive result was the very high alanine levels in totally pancreatectomized diabetic patients during normal insulin availability. Alanine is the key metabolite of gluconeogenesis [46], and glucagon is a determinant of hepatic alanine uptake [41]. Hyperalaninaemia in patients with pancreatic glucagon deficiency can be explained by reduced splanchnic uptake. This finding is in agreement with the report of Rabin et al. [47], showing a decrease in alanine splanchnic uptake in normal subjects after infusion of somatostatin plus insulin in order to obtain a selective glucagon deficiency. The greater insulin sensitivity of pancreatogenic diabetic patients can also lead to an exaggerated pyruvate production with subsequently increased alanine synthesis through aminotransferase [48].

The drastic difference between totally pancreatectomized and Type 1 diabetic patients suggests that gluconeogenesis is still activated by high pancreatic glucagon levels in spite of normal insulin availability. This is in agreement with the recent observation of Cherrington et al. [49], who demonstrated that gluconeogenesis activation by hyperglucagonaemia in dogs is not inhibited by portal insulin replacement.

A possible effect of the high-carbohydrate and lowfat diet received by the pancreatectomized subjects on alanine and ketone body concentration ought to be considered. In fact, this diet could affect ketone body production and activate the alanine-ketone body cycle [50]. However we exclude such a hypothesis, since the same diet was used for the partially pancreatectomized as well as for the totally pancreatectomized patients, but only the latter differ from the patients with Type 1 diabetes.

The role of glucagon in lipid metabolism is still controversial $[15,16,51]$. During Biostator use metabolites of lipolysis were blunted in primary and secondary diabetic patients as a consequence of steady hyperinsulinaemia due to peripheral infusion [52]. The mean level of glycerol during the intensive subcutaneous insulin therapy was higher in totally pancreatectomized patients. Since lipolysis was blunted by insulin replacement, as confirmed by similar NEFA levels in all groups, the enhanced glycerol concentration in totally pancreatectomized subjects further supports reduced gluconeogenesis. Under conventional therapy patients with secondary diabetes showed a slower increase in ketone body levels during the post-absorptive period than patients with Type 1 diabetes. This finding confirms the primary ability of insulin to control lipid metabolism but sug- gests a reduced tendency to ketosis in diabetes following pancreatectomy.

Finally, our data suggest that insulin replacement in totally pancreatectomized patients does not reverse the metabolic features observed in poorly controlled patients $[14,15,25]$. The marked difference in gluconeogenic precursors between pancreatic glucagon-deficient diabetic patients (total pancreatectomy) and diabetic patients with persistent (partial pancreatectomy) or high glucagon levels (Type 1 diabetes) suggests that gluconeogenesis activation does not depend on insulin availability. Thus our results favour the hypothesis that pancreatic glucagon plays an important role in diabetic hyperglycaemia.

Acknowledgements. We thank Miss N.Laughnane for her helpful English revision. This study was supported by the National Council for Research (grants CNR-810045283 and CNR-CT 810308511).

\section{References}

1. Unger RH, Orci L (1975) The essential role of glucagon in the pathogenesis of diabetes mellitus. Lancet 1:14-16

2. Sakurai H, Dobbs RE, Unger RH (1975) The role of glucagon in the pathogenesis of the endogenous hyperglycaemia of diabetes mellitus. Metabolism 24: 1287-1297

3. Schade DS, Eaton RP (1975) Modulation of fatty acid metabolism by glucagon in man. Effects in insulin deficient diabetics. Diabetes 24: $510-515$

4. Sherwin RS, Fisher M, Hendler R, Felig P (1976) Hyperglucagonemia and blood glucose regulation in normal, obese and diabetic subjects. New Engl J Med 294: 455-461

5. Aguilar-Parada E, Eisentraut AM, Unger RH (1970) Pancreatic glucagon secretion in normal and diabetic subjects. Am J Med Sci 257: 415-428

6. Unger RH, Aguilar-Parada E, Muller WA, Eisentraut AM (1970) Studies of pancreatic alpha cell function in normal and diabetic subjects. J Clin Invest 49: 837-848

7. Muller WA, Faloona GR, Unger RH (1970) Abnormal alpha cell function in diabetes: response to carbohydrate and protein ingestion. N Engl J Med 283: 109-115

8. Buchanan KD, McCarrol AM (1972) Abnormalities of glucagon metabolism in untreated diabetes mellitus. Lancet 2: 1394-1395

9. Liljenquist YE, Bomboy YD, Lewis SB, Sinclair-Smith BC, Felts PW, Lacy WW, Crofford OB, Liddle GW (1974) Effects of glucagon on lipolysis and ketogenesis in normal and diabetic men. $\mathrm{J}$ Clin Invest 53: 190-197

10. Gerich JE, Lorenzi M, Bier DM, Schneider V, Tsalikian E, Karam JH, Forsham PH (1975) Prevention of human diabetic ketoacidosis by somatostatin: evidence for an essential role of glucagon. $\mathrm{N}$ Engl J Med 292: 985-989

11. Bank S (1966) The management of diabetes in the unprivileged with special reference to pancreatic diabetes. S Afr Med J 40: 342-345

12. Bank S, Marks IN, Vinik AI (1975) Clinical and hormonal aspects of pancreatic diabetes. Am J Gastroenterol 64: 13-22

13. Dettwyler W (1964) Le diabète des pancréatopathies. Sem Hôp Paris 40: 1676-1682

14. Barnes AJ, Bloom SR, Mashiter K, Alberti KGMM, Smythe P, Turnell D (1977) Persistent metabolic abnormalities in diabetes in the absence of glucagon. Diabetologia 13: 71-75

15. Barnes AJ, Bloom SR, Alberti KGMM, Smythe P, Alford FP, Chisholm DJ (1977) Ketoacidosis in pancreatectomized man. N Engl J Med 296: 1250-1253

16. Del Prato S, Nosadini R, Riva F, Fedele D, Devidè A, Tiengo A (1980) Glucagon levels and ketogenesis in human diabetes follow- 
ing total or partial pancreatectomy and severe chronic pancreatitis. Acta Diabetol Lat 17: 111-118

17. Lloyd B, Burrin J, Smythe P, Alberti KGMM (1978) Enzymic fluorimetric continuous-flow assay for blood glucose, lactate, pyruvate, alanine, glycerol and 3-hydroxybutyrate. Clin Chem 24: $1724-1729$

18. Price CP, Lloyd B, Alberti KGMM (1977) A kinetic spectrophotometric assay for rapid determination of acetoacetate in blood. Clin Chem 23: 1893-1897

19. Shimuzu S, Inone K, Tani Y, Yamada H (1979) Enzymatic microdetermination of serum free fatty acids. Anal Biochem 98: $341-345$

20. Nagakawa S, Nakayama H, Sajaki T, Yoshino K, Yu YY, Shinozaki K, Aoki S, Mashimo K (1973) A simple method for the determination of serum free insulin levels in insulin-treated patients. Diabetes 22: 590-600

21. Faloona GR, Unger RH (1974) Glucagon. In: Jaffe BM, Berhman HR (eds) Methods for hormone radioimmunoassay. Academic Press, New York, pp 317-330

22. Harkins WD, Holladay L (1980) A temperature conversion monogram for glycosylated haemoglobin analysis. Clin Chim Acta 104: 251

23. Kuzuya T, Matsuda A, Saito T, Yosluda S (1976) Human C-peptide immunoreactivity in blood and urine, evaluation of a radio immunoassay method and its clinical applications. Diabetologia 12: $511-518$

24. Valverde I, Villaneuva ML, Lozano I, Marco J (1974) Presence of glucagon immunoreactivity in the globulin fraction of human plasma ('big plasma glucagon'). J Clin Endocrinol Metab 39: 1090-1098

25. Valverde I, Dobbs R, Unger RH (1975) Heterogeneity of plasma glucagon immunoreactivity in normal, depancreatized and alloxan diabetic dogs. Metabolism 24: 1021-1028

26. Service FJ, Molnar GD, Rosevear JW, Ackerman E, Gatewood LC, Taylor WF (1970) Mean amplitude of glycemic excursions, a measure of diabetic instability. Diabetes 19:644-655

27. Newman D (1939) The distribution of range in samples from a normal population, expressed in terms of an independent estimate of standard deviation. Biometrika $31: 20-30$

28. Keuls M (1952) The use of the 'studentized range' in connection with an analysis of variance. Euphytica 1: 112-122

29. Barnes AJ, Bloom SR (1976) Pancreatectomized man: a model for diabetes without glucagon. Lancet 1:219-221

30. Tiengo A, Bessioud M, Valverde I, Tabbi-Anneni A, Del Prato S, Alexandre J, Assan R (1982) Absence of islet alpha cell function in pancreatectomized patients. Diabetologia 22: 25-32

31. Miyata $M$, Yamamoto $T$, Yamaguchi $M$, Nakao $K$, Yoshida $T$ (1974) Plasma glucagon after total resection of the pancreas in man. Proc Soc Exp Biol (NY) 147: 97-102

32. Muller WA, Berger M, Suter P, Ceippers HJ, Reiter J, Wyas T, Berchtold P, Schmidt FH, Assal JP, Renold AE (1979) Glucagon immunoreactivities and amino acid profile in plasma of duodenopancreatectomized patients. J Clin Invest 63: 820-827

33. Palmer JP, Werner PL, Benson JW, Ensick JW (1976) Immunoreactive glucagon responses to arginine in three pancreatectomized humans. Metabolism 25 (Suppl 1): 1483-1485

34. Boden G, Master RW, Rezvani I, Palmer JP, Lobe TE, Owen OE (1980) Glucagon deficiency and hyperaminoacidemia after total pancreatectomy. J Clin Invest 65: 706-716

35. Damman HG, Besterman HS, Bloom SR, Schreiber H (1981) Guthormone profile in totally pancreatectomized patients. Gut 22: 103-107

36. Sherwin RS, Fischer M, Bessoff J, Snyder R, Hendler R, Conn HO, Felig P (1978) Hyperglucagonemia in cirrhosis: altered secretion and sensitivity to glucagon. Gastroenterology 74: 1224-1228
37. Perez G, Trimarco B, Ungaro B, Rengo F, Saccà L (1978) Glucoregularity response to insulin-induced hypoglycaemic in Laennec's cirrhosis. J Clin Endocrinol Metab 46: 778-783

38. Nosadini R, Del Prato S, Tiengo A, Duner E, Toffolo G, Cobelli C, Faronato PP, Moghetti P, Muggeo M (1982) Insulin sensitivity, binding and kinetics in pancreatogenic and Type I diabetes. Diabetes 31 : $346-355$

39. Del Prato S, Ruggeri A, Tessari P, Moghetti P, Manunta R, Duner E, Avogaro A, Fedele D (1981) Reduced insulin sensitivity (IS) in Type I diabetics. Diabetes 30 (Suppl 1): 331 (Abstract)

40. DeFronzo RA, Handler R, Simonson D (1982) Insulin resistance is a prominent feature of insulin-dependent diabetes. Diabetes 31 : 795-801

41. Cherrington AD (1981) Gluconeogenesis: its regulation by insulin and glucagon. In: Brownlee M. (ed) Diabetes mellitus, Vol. III, Sarland STPM Press, New York, pp 49-117

42. Wahren J, Hagenfeld L. Felig P (1975) Splanchnic and leg exchange of glucose, amino acids and free fatty acids during exercise in diabetes mellitus. J Clin Invest 55: 1305-1314

43. Pozefsky T, Tancredi RG, Moxley RT, Dupre J, Tobin JD (1976) Metabolism of forearm tissues in man studies with glucagon. Diabetes 25: 128-135

44. Ochs RS, Harris RA (1980) Glucagon and $\mathrm{N}^{6}, \mathrm{O}^{21}$-dibutyril adenosine $3^{\prime}-5^{\prime}$ monophosphate. Inhibition of lipigenesis and phosphofructokinase activity of hepatocytes from meal-fed rats. Lipids 15 : 504-511

45. Goriya Y, Bahoric A, Marliss EB, Zinman B, Albisser AM (1981) The metabolic and hormonal responses to a mixed meal in unrestrained pancreatectomized dogs chronically treated by portal or peripheral insulin infusion. Diabetologia 21: 59-64

46. Felig P, Pozefsky T, Marliss E, Cahill GF Jr. (1969) Alanine key rôle in gluconeogenesis. Science 167: 1003-1004

47. Rabin D, Müller GL, Lacy WW, Liljenquist JE (1979) Splanchnic metabolism of alanine in intact man: effects of somatostatin and somatostatin plus insulin. Diabetes $28: 486-490$

48. Pozefsky T, Tancredi RG (1972) Effects of intrabrachial arterial infusion of pyruvate on forearm tissue metabolism. Interrelationships between pyruvate, lactate and alanine. J Clin Invest 51: 2359-2369

49. Cherrington AD, Williams PE, Shulman GI, Lacy WW (1981) Differential time course of glucagon's effect on glycogenolysis and gluconeogenesis in the conscious dog. Diabetes 30:180-187

50. Nosadini R, McCulloch A, Del Prato S, Avogaro A, Alberti KGMM (1982) The relationship between alanine and ketone body in vivo. Metabolism 31: 1175-1178

51. Lefebvre $P(1972)$ Glucagon and lipid metabolism. In: Lefebvre $P$, Unger RH (eds) Glucagon: molecular physiology, clinical and therapeutic implications. Pergamon Press, New York, pp 109-121

52. Nosadini R, Noy GA, Nattrass M, Alberti KGMM, Home PD, Johnston DG, Ørskov H (1982) The metabolic response to shortterm normoglycaemia in insulin-deficient diabetes: studies with a glucose controlled insulin infusion system (artificial endocrine pancreas). Diabetologia 23: 220-228

Received: 20 July 1982

and in revised form: 15 June 1983

Dr. Stefano Del Prato

Divisione di Gerontologia e Malattie del Ricambio

Policlinico, Via Giustiniani n. 2

I-35100 Padova, Italy 